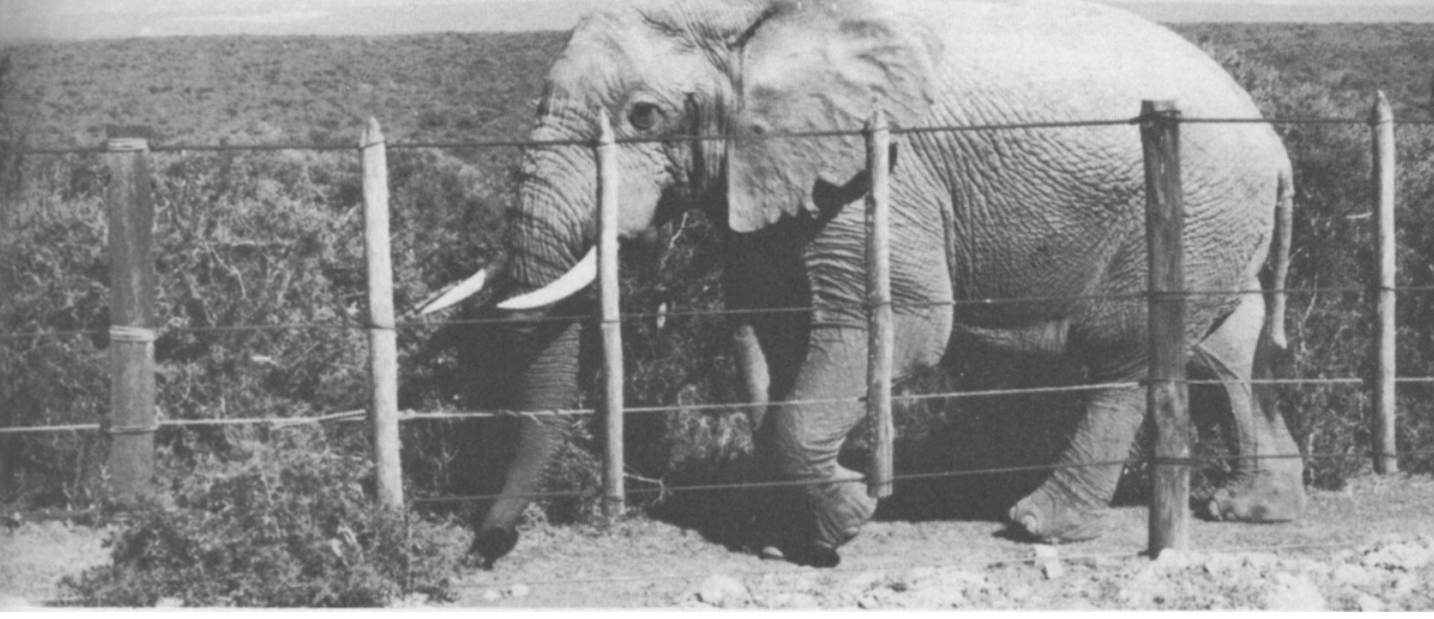

\title{
Elephant Survivors
}

\section{Anthony Hall-Martin}

Three small elephant populations have survived in South Africa despite near extermination in the recent past. In Tongaland a group of fewer than 30 bulls survives by keeping contact with the population in a nearby reserve; in the Knysna, where there were 13 in 1920, there are now 12; and in the Addo Bush 11 survivors in 1931 had increased to only 18 in 1953, but to 102 in 1979: The author tells the story of each group, discusses the reasons for the different status of each, and describes what is being done to conserve them.

The African elephant paradox - of excessive populations having to be culled in some areas and dwindling populations in others - is nowhere more striking than in South Africa. In the Kruger National Park, 7719 elephants have been culled over the past decade; at the same time three isolated, relict populations have been for many years dangerously close to extinction.

In the 19th century Loxodonta africana, like many other species of the rich South African fauna, was virtually exterminated thanks to the lure of rich profits in the ivory trade, and by 1900 the only survivors were the remnants of the Cape Province's herds in the forests near Knysna and in the Addo Bush, together with a little known population in Tongaland, straddling the Mozambique border. Since then the Knysna elephants have declined even further, and the Tongaland breeding herds have disappeared; the Addo elephants, however, having come within a hair's breadth of extinction, have recovered spectacularly. The Kruger, on the other hand, has been recolonised by immigrants from Mozambique, which also pressed westwards into privately owned nature reserves. Because of their increasing numbers and their impact on the habitat, the Kruger elephants have been culled to maintain the population at about 7500 , the estimated carrying capacity of the park.

Above: BULL ELEPHANT behind the Armstrong fence in the Addo Elephant National Park Anthony Hall-Martin 


\section{Tongaland}

The north-eastern border area of Natal is locally known as Tongaland. Bounded on the west by the Lebombo Mountains and Swaziland, to the north by Mozambique, and to the east by the Indian Ocean, it is a vast sandy coastal plain. In the Pleistocene it was submerged; today it is covered in a mosaic of sour coastal grasslands, rich evergreen swamp forests, dense impenetrable deciduous thickets and forests, reed beds, pans and small lakes. The western and coastal areas are heavily populated by Thonga tribesmen, but the sparsely inhabited central part, between the Pongola River and the Mosi Swamp, is a refuge for the last elephants in South Africa living outside a protected area. Incessant persecution has reduced them to a fluctuating population of only about 20-30, all bulls; the last confirmed reports of resident breeding herds were 30 years ago. Some may be resident in the area; others wander to and fro across the boundary with Mozambique, where they still retain a tenuous contact with the Maputo Elephant Reserve population. That they have survived at all is due to the remoteness of the areas they frequent and the absence until recently of roads and settlements.

In the wet season, when water is abundant in numerous small pans, the elephants move southwards. The resulting damage to the ripening crops of the rapidly expanding human population and also to the veterinary fence on the international boundary (to control foot-and-month disease) naturally incurs the wrath of both local people and the authorities. The nature conservation authorities are trying to confine the elephants to an area of about 50,000ha of largely uninhabited country lying between the Mozambique border and the Ndumi-Kosi Bay road, but this is only possible if the elephants can get to water on the edge of the Mosi Swamp, as in drought periods the rest of the area is waterless. At night the conservation staff under Bob Langeveld, a seasoned veteran with a great love of elephants, engage in noisy patrols to dissuade the elephants from crossing the road into the more densely settled areas. It is still necessary occasionally to shoot marauding bulls, and at least 10 animals have been killed in the last five years. Most were found to have multiple bullet wounds or snare injuries, grim evidence of their constant harassment. Numbers are still declining, but there is still some recruitment of young bulls; 15-20-year-old animals are regularly seen, and the nearest breeding herd from which they could have originated is in the Maputo Elephant Reserve in Mozambique.

With the development of political institutions among the local people, who fall under the recently constituted Government of KwaZulu, responsibility for conservation is passing into black hands. A small, but growing conservation department, with trained black officers, is negotiating with the tribal landowners to secure the area used by the elephants, which is not suitable for agriculture, as a wildlife reserve, and also trying to convince the tribal leaders of the value of using it to conserve wildlife, of which it could support a wide spectrum. This positive attitude of the government and the tribal people towards creating a viable wildlife reserve has been actively supported by the Conservation Trust of KwaZulu, recently formed and privately sponsored under the chairmanship of a Johannesburg businessman, Les Luckhoff, and by the Endangered Wildlife Trust chaired by Clive Walker. Iain DouglasHamilton, Director of the IUCN/WWF Elephant Survey and Conservation Programme, also attaches the highest priority to the establishment of this 


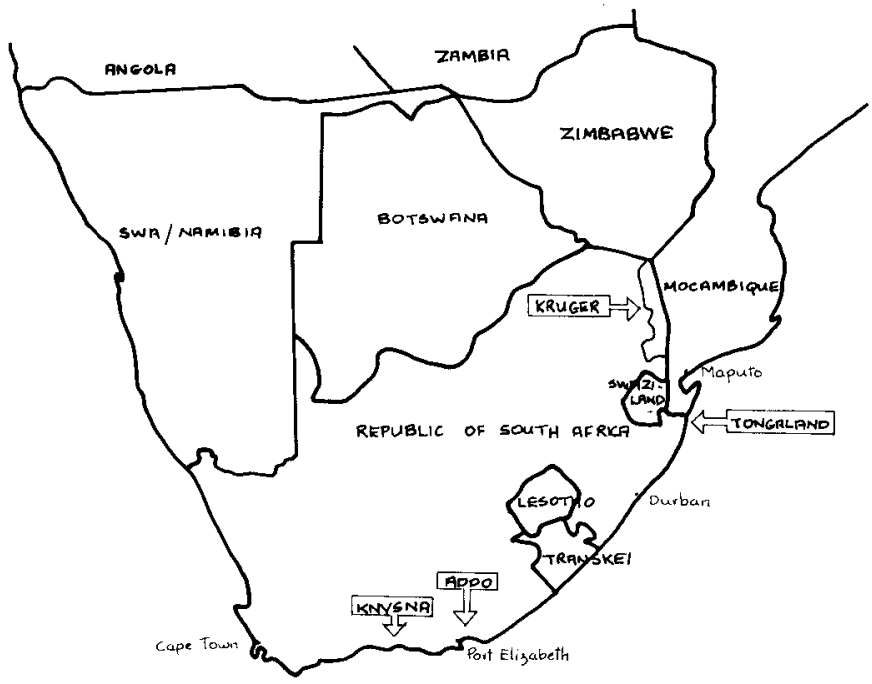

wildlife reserve to ensure the survival of these elephants. But such a reserve will only be the first step towards maintaining a viable elephant population in Tongaland. But with settlement and development on both sides of the border and the inevitable political tensions, the thread of contact between the Tongaland elephants and those in the Maputo Elephant Reserve is certain to be cut, and if no cows are found to live permanently in Tongaland or move in from Mozambique and settle there - and this is increasingly unlikely - the prospects are not encouraging. The best course to stabilise the elephant population would then seem to be to construct an Addo-type elephant-proof fence around the whole area and introduce females - from the Kruger National Park if none can be obtained from the Maputo Reserve.

\section{The Knysna Elephants}

The Knysna forests lie on the southern coast of the Cape Province, where mountain ranges, such as the Outeniqua and Tsitsikama, cut off a narrow coastal shelf from the interior. Rainfall on the seaward side of the mountains is much higher than elsewhere in South Africa and distributed throughout the year, with frequent cloudy weather to ameliorate the dry periods. These climatic conditions, combined with suitable soils, topography and temperature, have resulted in the development of evergreen forests closely related to the mountain forests of East Africa. Along the coast and ascending the mountains the high forest grades into scrub forest and Cape macchia. Historically these forests, like their East African counterparts, were known for the excellence of their timber and the large number of elephants and other game.

From about 1763, white settlers established themselves in the Knysna area as woodcutters, farmers and elephant hunters. A short-lived gold rush from 1860 to 1890 brought in more whites and drastically increased the pressure on the elephants as more land was taken over for development and the trade in ivory expanded. During this period of increasing slaughter the first plea for the protection of the Knysna elephants was made by Captain Christopher Harison, Conservator of Forests. ${ }^{2}$ In November 1876, he reckoned there were only between 400 and 500 left. Over the next 30 years as the elephants declined to between 40 and 50, his successors repeated his plea, but the Colonial 
government was not unduly concerned. The forestry officers had no authority to protect the elephants when they moved off forestry land, and even though in 1908 they were proclaimed Royal Game noboby was appointed to enforce the decree. By 1920 when only 18 elephants were left, a permit was issued to Major P.J. Pretorius, a noted elephant hunter of the time, to shoot one animal for 'science' - ostensibly to settle the question of whether the Knysna elephants were a distinct subspecies (L.a.toxotis of Dr Lydekker) or not. The hunt was a disaster; the Major got into difficulties, and five elephants were killed-leaving only 13 animals.

Since then the population has remained static, and the latest available estimate of their numbers, made in 1973, was that there were 12 - two old bulls, two prime bulls, one young bull, one old cow, four adult cows and two calves of unknown sex. But there is still some doubt as to the size and composition of the population. Little is known about the lives of these elephants other than what has been recorded by officers of the Forestry Department and a brief survey sponsored by the Wildlife Society of South Africa. ${ }^{1}$ They roam over an area of some $32,000 \mathrm{ha}$ of state-owned indigenous forests (about 20 per cent exploited, the rest reserved), plantations and privately owned forest land. There are no impediments to their movement and they occasionally visit small private agricultural plots bordering the forests, where they cause minor damage to crops, orchards and fences. Generally they are reported to move seasonally from the mountains to the coast, but opinions differ. From observations on their choice of food and impact on the forest ${ }^{4}$ both state and private foresters agree that the present level of damage to commercially valuable timber is not important.

The Department of Forestry follows a policy of ecosystem conservation in the reserves under its control. In the Knysna forests the elephants are regarded as an integral part of the forest system, and are thus afforded full protection while on forestry department land. But once they cross on to private land they fall under the jurisdiction of the Cape Department of Nature Conservation. The larger private landowners tolerate the elephants, but the smallholders complain about them and, it is alleged, drive them off their plots by shooting at them. So, apart from the chance of being killed or wounded by the odd irate smallholder, it seems as though all is well with the Knysna elephants. But is this in fact so? In a period of over 50 years, between 1920 and 1973, numbers went down from 13 to 12 . Should the population have increased, and if so, why has it not?

Two main explanations are put forward. ${ }^{3}$ The first is that the static population is normal and there is no conservation problem, which does not fit easily with what we know of the performance of other isolated relict elephant populations. It rests on one or more of three assumptions: that the elephant population is in a state of equilibrium with its food supply; that the low numbers are due to a small initial population (of 1920) combined with a higher incidental periodic mortality; that births are balanced by deaths due to natural causes. The second argument is that the stagnation of this population is abnormal and results from artificial factors of three possible kinds: adverse effects of in-breeding in such a small population; poor nutrition in their present range resulting in a lower reproductive rate (as opposed to better nutrition in their former range, which included non-forest biomes); high mortality due to illegal shooting. 
The arguments are mostly speculative, and counter-arguments equally so. If the Knysna elephant population is self regulating (i.e. in balance with its environment) it will be the only known elephant population presently in that happy state. There is no good evidence from Knysna to support the assumption that the elephants' reproduction is limited by the quantity or quality of their food supply. The large numbers of elephants that inhabited the forests as recently as a century ago may have used a wider range of vegetation types, including forest shrub and macchia. There is no good evidence of any regular movements away from the forests; travellers and chroniclers apparently found elephants in the forests at all times of the year. The Knysna elephants when seen are invariably in good condition, as were the animals in 19 photographs that I have examined (on the evidence of several easily assessed physical features). The small size of the 1920 population is not critical, nor is it likely that inbreeding has been of any consequence; by comparison the 11 Addo elephants in 1931 had increased by 1979 to 102 with no signs of genetic abnormality.

It therefore seems possible that the population has been influenced by higher than normal mortality. Estimates of natural calf mortality of 60-80 per cent, put forward to explain the low numbers, contrast strikingly with a known mortality rate of 7.5 per cent for calves at Addo, where good data on births and deaths have been recorded since 1954, unless the high mortality is due to some outside factor. If so the most likely one is man. Opinions conflict on the role of illegal shooting, but Carter ${ }^{1}$ states that he found good evidence of at least four elephants having been shot between 1940 and 1970, and we know of a bull shot in 1971. None of these shootings was by commercial poachers. By contrast only two calves are known to have died of natural causes. There is a striking parallel at Addo where in the decade 1943-1953 eight calves were born and eight animals were shot - mostly by farmers trying to chase elephants from their crops, waterholes and fences; it was not until this source of mortality was removed by enclosing the elephants inside an elephant-proof fence that the population increased - from 18 in 1953 to 102 today. If the Knysna elephants are not being killed by man, the most convincing argument as to why they should not increase lies in the effect of nutrition on their reproduction; but there is no evidence at present to substantiate this point.

The Department of Forestry has approved a research project that will seek to answer some of the many questions raised about the Knysna elephant numbers, population composition, reproduction, mortality, distribution, movements and food. If the results show that the present food supply or quality is limiting the population then the only means of overcoming the problem may be to make other non-forest biomes available to the elephants. Because of settlement and development in such areas this may be very difficult to achieve. If, however, it is found that man is the culprit, then the Forestry Department will, hopefully, take steps to eliminate this cause of mortality by enclosing the elephants in a suitable area, as was done at Addo and is advocated by local conservationists - an expensive but not impossible undertaking - or perhaps better still by a judicious policy of buying out problem smallholdings (if these are proved to exist) and fencing off the rest from state forest reserves. Whatever is done there will still be an upper limit to the numbers that the forests can carry, above which elephant damage will be unacceptable to both the pecuniary and forest conservation interests involved. But the present 
population of 12 animals, of which only four appear to be cows of breeding age, is uncomfortably close to extinction, and a larger population must be a minimum requirement for their survival.

\section{Addo Elephants}

The Addo Bush is the local name of an extensive, low, dense thicket of evergreen shrubs, succulents and small trees at the point where the flora of the moist southern Cape biome, the arid interior Karoo and the tropical East African littoral meet and intergrade. The country is gently undulating between the Sundays River, the Zuurberg Mountains and the shores of Algoa Bay on the Indian Ocean, about $70 \mathrm{~km}$ from the harbour city of Port Elizabeth. With a density of 15,000 to 20,000 stems per hectare, a height of $3-4 \mathrm{~m}$ and visibility limited to little more than $2 \mathrm{~m}$, the thicket fits anybody's idea of 'impenetrable jungle'. Add to this the thorns and spines of many of the shrubs, the lack of permanent water, the intense summer heat, prolonged droughts and irregular rainfall (about 15in. per year) and it is easily understood why the area was avoided by both black settlers and the whites who arrived at the end of the 18th century. The elephants that lived in the bush, or retreated to it, were relatively safe from the ivory hunters who wiped out their comrades outside.

But roads, railways, irrigation dams and canals brought settled agriculture ever closer, and by the beginning of this century the Addo Bush was an island, so isolated that not even the great rinderpest epidemic reached its last herds of Cape buffalo. Large areas of the natural vegetation were cleared for crops and citrus, and the animals were increasingly cut off from their traditional watering points in the Sundays River and the streams issuing from the Zuurberg. They had to move out of the bush to get water and in the process broke fences and raided crops. The stage was set for the inevitable showdown between man and elephants. The settlers set out to exterminate the elephants. The government, ever ready to satisfy public opinion, gave the commission to Major P.J. Pretorius, the man who a year later was to wreak such havoc on the Knysna

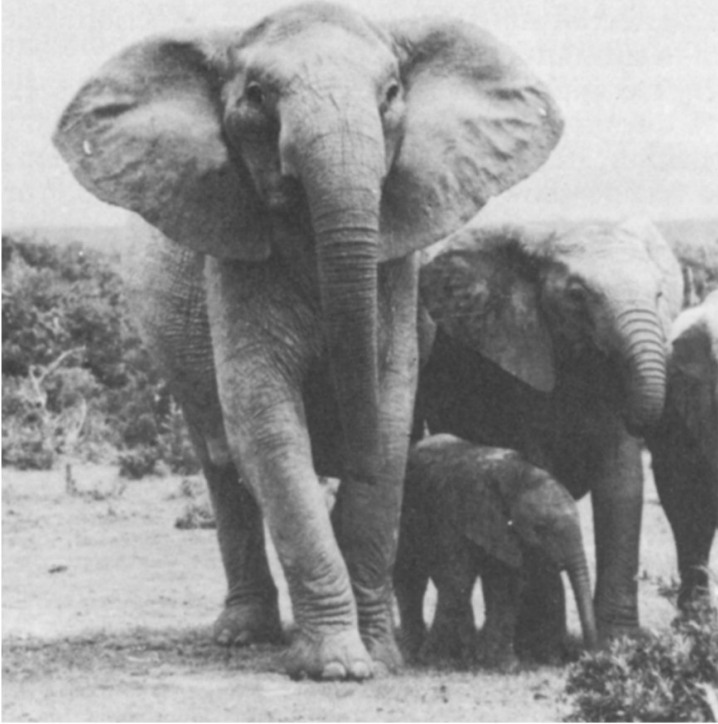

Left and opposite: In the Addo National Park all cow elephants except four are without tusks. This may be due to 19thcentury hunters selecting for ivory. 
elephants. Over a period of 11 months Pretorius shot a great number: estimates varied from 90 to 120 depending on whether one was for or against the elephants. Pretorius's great skill and courage, and his increasingly suicidal methods of getting at the elephants in that terrible country, attracted a great deal of publicity and, later, sympathy for the surviving elephants both from Pretorius himself and the general public. The hunt was called off, and the fledgling Wildlife Society of South Africa successfully pressed for the elephants to be protected. In 1931 the Addo Elephant National Park with its sorry band of 11 surviving elephants was proclaimed.

The game warden's first task was to provide adequate water and drive the scattered elephants into their sanctuary. He succeeded, but the animals still regularly wandered out, the running battle with the farmers continued, and gunshot wounds continued to take a heavy toll. At this time the Addo Bush elephant was still regarded as a distinct sub-species L.a.capensis and as such it was included in the first list of endangered species drawn up by the IUCN in 1949. It was only after Graham Armstrong, the enterprising warden, in 1953 perfected his elephant-proof fence of tram lines and elevator cables that the elephants could be confined to a 2270-ha area (5609 acres) of the park's total 7735 ha $(19,113$ acres), and the shooting stopped. This was enough to ensure the survival of the Addo elephants, and numbers increased rapidly, from 18 in 1953 to 102 in 1979, a rate of seven per cent a year, which shows no sign of letting up.

The result is the inevitable, but not yet drastic, habitat change associated with elephants at high densities, and in 1976 a research project was started to quantify the changes in the vegetation and to study the ecology, population dynamics and behaviour of the elephants. From a series of 60 plots where vegetation was sampled it was found that by the end of 1977 the elephants had caused a significant decline in density, biomass and species composition of the vegetation. In anticipation of these findings, however, the National Parks Board of Trustees had already approved the extension of the Armstrong fence to increase the elephant range in the park to 3953 ha ( 9768 acres), and this now supports a crude population density of 2.4 elephants per sq $\mathrm{km}$. This together with buffalo, black rhinoceros, bushpig, kudu, and other antelopes gives a total animal biomass in the area of $6726 \mathrm{~kg}$ per sq $\mathrm{km}$, by far the highest animal biomass yet recorded in southern Africa. Appropriate reductions in the numbers of other animals will be made this year. By end-1980 another 1174 ha (2901 acres) will be added to the elephant range, and a final enlargement will increase the elephant range to its maximum size of about $6735 \mathrm{ha}$ (16,642 acres) 
or about 87 per cent of the Park. The remaining 13 per cent is zoned as witness areas of vegetation excluded from the elephant range for strict botanical protection, and development areas (park headquarters, staff village, tourist camp).

Our studies on the carrying capacity of the park are not yet completed, but it seems likely that the maximum elephant population will be reached by 1984 , and a programme to limit it to the estimated carrying capacity decided upon, not necessarily by killing surplus elephants. It may be possible to buy more adjoining land and so increase their range, although this can only be a short-term solution because agriculture has so altered most of the surrounding land that it could not support many elephants.

A better solution would be to move the surplus to other suitable conservation areas within the East Cape elephant's historical range. The expertise for this is available, successful translocations have already been made from the Kruger to other areas, and from Addo to the Pilanesberg Game Reserve. Both the Zuurberg and Groendal Forest Reserves, which are managed as wilderness conservation and catchment protection areas by the Department of Forestry, would provide suitable habitat and are close to Addo. The Andries Vosloo Kudu Reserve of the Cape Department of Nature Conservation is also excellent habitat. If the two Departments felt that the introduction of elephants to these areas would not conflict with their conservation or management priorities and the necessary funds could be raised, the distasteful prospect of killing those elephants, which have become a symbol of conservation success in South Africa, could be avoided.

\section{Acknowledgments}

I should like to thank Bob Langeveld, Piet Odendaal, Johan Breytenbach and Clive Walker for their co-operation, information and critical comments.

\section{References}

1 CARTER, Nick 1970. Knysna elephant survey. Report to the Wildlife Protection and Conservation Society of South Africa.

2 PHILLIPS, J.F.V. 1925. The Knysna elephant: a brief note on their history and habits.S.Afr. F.Sci. 22: 287-293.

3 SEYDACK, A.H.W. 1978. Game management on state forest land in the Southern Cape. Typescript seminar; Department of Forestry, University of Stellenbosch.

4 VON GADOW, K. 1973. Observations on the utilization of indigenous trees by the Knysna elephants. For. in S.Afr. 14: 13-17.

Dr A. Hall-Martin, Kruger National Park, Private Bag X404, Skukuza 1350.

\section{Clean Food for Sea Eagles}

In 197912 out of 14 pairs of white-tailed sea eagles nested successfully on Sweden's east coast, but in Lapland only six of 22 known pairs did so; a seventh young bird was taken by a bear that climbed the nesting tree. The eagles are monitored under a research and conservation project started in 1971 by the Swedish Society for the Conservation of Nature and directed by Bjørn Helander. The chief threats to the eagles are poisons in the environment, clear-felling in nesting areas and human disturbance at nesting sites. Moreover, although protected since 1924, birds are still shot - one was found north of Stockholm last summer. Under the Society's project, nests are protected and food provided - last winter over 120 tons was put out for eagles at over 100 sites, and unpolluted food is provided at the breeding sites. As a result mortality among young birds has decreased and the number coming to winter feeding sites has increased. 